\title{
Publisher Correction: Increased expression and retention of the secretory chaperone proSAAS following cell stress
}

\section{Manita Shakya $^{1} \cdot$ Taha Yildirim $^{1} \cdot$ Iris Lindberg ${ }^{1}$}

Published online: 20 July 2020

(C) The Author(s) 2020

Publisher Correction: Cell Stress and Chaperones https://doi.org/10.1007/s12192-020-01128-7

Due to an unfortunate mistake in the production process, the the words 'increases' and 'decreased' were transposed in the penultimate citation of Viard et al. 1999. The original article has been corrected and the correct sentence is also published here and should read:

"however, during heat shock stress, decreases in cellular clusterin occur in parallel with increased secretion (Viard et al. 1999)."

Publisher's note Springer Nature remains neutral with regard to jurisdictional claims in published maps and institutional affiliations.

The online version of the original article can be found at https://doi.org/ $10.1007 / \mathrm{s} 12192-020-01128-7$

Iris Lindberg

ilindberg@som.umaryland.edu

1 Department of Anatomy and Neurobiology, School of Medicine,

University of Maryland, 20 Penn St, HSF2, S267,

Baltimore, MD 21201, USA 